\title{
Genetic Variation of Sago Palm (Metroxylonsagu Rottb.) Progenies with Natural Pollination by Using RAPD Markers
}

\author{
Barahima Abbas' ${ }^{1}$, Muhammad Dailami², Budi Santoso $^{3}$, Munarti $^{4}$ \\ ${ }^{1}$ Faculty of Agriculture, University of Papua (UNIPA), Manokwari, Indonesia; ${ }^{2}$ Faculty of Mathematics and Science, \\ University of Papua, Manokwari, Indonesia; ${ }^{3}$ Faculty of Agricultural Technology, University of Papua, Manokwari, \\ Indonesia; ${ }^{4}$ Faculty of Teacher Training and Education Science, The Pakuan University, Bogor, Indonesia
}

Correspondence to: Barahima Abbas, barahimabas@gmail.com

Keywords: Sago Palm, Genetic Variation, Progenies, RAPD Markers, Natural Pollination

Received: March 1, $2017 \quad$ Accepted: April 27, $2017 \quad$ Published: April 30, 2017

Copyright (C) 2017 by authors and Scientific Research Publishing Inc.

This work is licensed under the Creative Commons Attribution International License (CC BY 4.0).

http://creativecommons.org/licenses/by/4.0/

(c) (i) Open Access

\section{ABSTRACT}

Sago palm is flowering and fruiting just once in their life cycle. Sago palms that grow naturally and semi cultivated were generally occurred natural pollination to form fruits and seeds, if not cut down to take the starch contained in their trunk. Sago palm pollination may occur as self-pollinated and cross-pollinated. If cross-pollinated was occurred in the pollination process, it will be varied of their progenies. This study aims to reveal the genetic variation of sago palms progenies with naturally pollinated process. The research method is to collect seeds from one parent trees that have produced ripe fruit. Fruit seeds germinated to be made and tested genetic variation using RAPD markers. Isolation of DNA is done by using the fresh young leaves. DNA amplification is done by using RAPD primers. The results showed that the progenies derived from naturally pollinated of sago palms were genetically varied based on RAPD markers and also varied based on morphological phenotypic. Variations occurred in the progenies of sago palm indicated that the sago palms were estimated cross-pollinated naturally, as a result fruits and seeds with genetically differences.

\section{INTRODUCTION}

Sago palm is a starch-producing plant which is included in the family of Palmae and the genus of Metroxylon. This plant can grow in an environment where other plants cannot grow and resulting crops. The sago palm can tolerate salinity up to $171 \mathrm{mMNaCl}$ for their growth because sago palm possessed mechanisms to limit the distribution of $\mathrm{Na}$ from the roots to the leaves [1]. Sago palm growth falters in the media with $\mathrm{Al}$ content reaches $200 \mathrm{ppm}$ [2]. Potential of starch production of sago palm commodities is higher than other starch-producing plants. Starch production of sago palm was reported 3 to 4 times 
higher than the production of rice, corn or wheat and 17 times higher than the production of cassava [3]. [4] documented that the average productivity of sago palm each year up to 25 tons/ha. It makes sago become an important commodity that needs to be developed to meet the need for food and energy. Sago Starch has long been used by most of the local people in Papua as a staple food in the form of Papeda, Sinole, Kapurung, Sago Lempeng and Bagea [5]. Currently, a lot of variations of food made from sago starch, such as noodles, pastries, bread, cake, and brownies [6]

Sago palmsthat grow naturally and semi cultivated are naturally pollinated to form fruits and seeds, if not cut down to take the starch contained in the trunk. Sago palm pollination may occur as self-pollinated and cross-pollinated. Cross pollination leads to the expansion of genetic diversity due to recombination or segregation [7]. [8] reported that the type of sago palm pollination is cross-pollination, so the seeds that it is produced will diverse of their character. The phenotype characters will be expressed after the germination process to form seedling.

Information of plant genetic diversities is very important to be used for germ plasm collection and conservation. When germ plasm conservation activity is done, information of genetic diversities needed, especially from the natural habitat to carry out germ plasm conservation efficiently. A popular DNA markers used for revealing genetic diversities and genetic relationships are Random Amplified Polymorphism DNA (RAPD) markers. The RAPD marker is one of many techniques used for molecular biology research. The advantages of RAPD markers are simpler in their preparation than other molecular markers. The other advantages of RAPD markers are easy applied for examining the diversities of organism [10-12], because it is not using radioactive and relatively chief [9].

\section{MATERIALS AND METHODS}

\subsection{Sample Collection}

Young leaf of sago palm samples were collected from sago palm seedlings that is grown from seeds. The seeds were collected from one sago palm tree at the fruiting stages. A total 10 samples of 100 seedlings were selected and used in this study (Figure 1). Sago palm leafs were cleaned by using wet tissue with alcohol $70 \%$. Approximately 0.5 gram fresh young leaves were used for isolation and extraction DNA. Isolation and extraction of total DNA from fresh sago palm leaf samples were conducted by using procedures as described by Geneaid DNA extraction kit (Geneaid, 2016). The total DNA was stored in $-20^{\circ} \mathrm{C}$ in freezer until ready for using.

\subsection{PCR Amplification}

PCR reactions were performed by using a machine Gene Cycler, Biorad. RAPD primers were used as follows OPA1 (5'-CAGGCCCTTC-3'), OPAW05 (5'-CTGCTTCGAG-3'), OPD08 (5'-GTGTGCCCCA-3'),
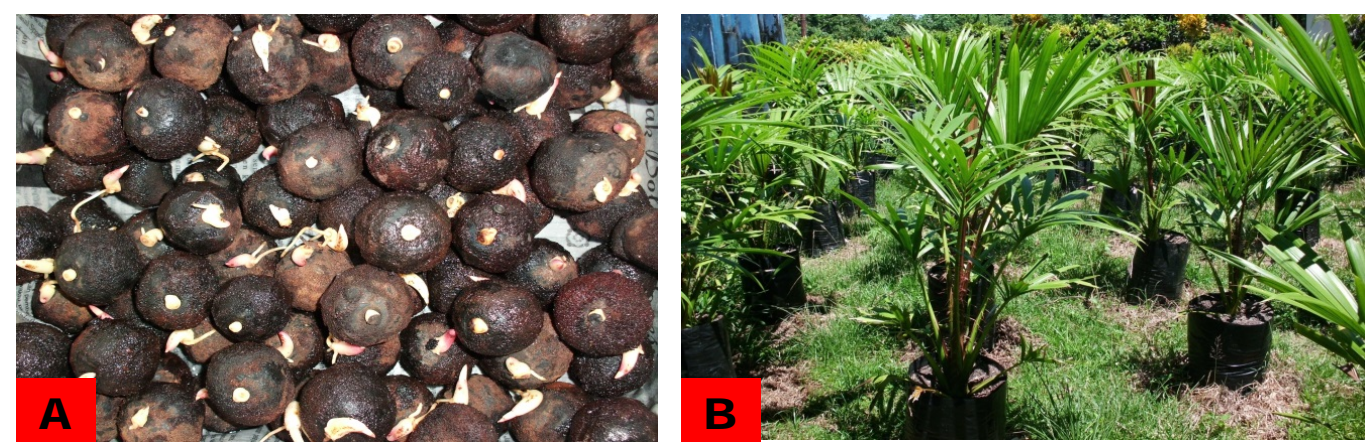

Figure 1. Performance of plant material used as sample in the study. Sprouting seeds (A) seedlings that is growing from the seeds after 10 months in the nursery were used as leaf sample for DNA isolation (B). 
P01 (5'-GCGGCTGGAG-3'), OPA04 (5'-AATCGGGCTG-3'). The decamer random primers were provided original sequences by Operon Technologies, Alameda, USA and synthesized by Integrated DNA Technologies. Reagents used are Go-Taq-Green Master Mix kit, Promega. The PCR reaction with a total volume of $10 \mathrm{ml}$ consisting of $3 \mathrm{ml} \mathrm{ddH} 2 \mathrm{O}, 5 \mathrm{ml} \mathrm{Go}$-Taq-Green mastermix, RAPD Primer $1 \mathrm{ml}$, and $1 \mathrm{ml}$ of genomic DNA samples. Temperature profile used was $80^{\circ} \mathrm{C}$ for 10 second, $94^{\circ} \mathrm{C}$ for 2 minutes, 35 cycles consisting of three steps $\left(94^{\circ} \mathrm{C}\right.$ for 30 seconds for denaturation, $40^{\circ} \mathrm{C}$ for 60 seconds for annealing and $72^{\circ} \mathrm{C}$ for 90 seconds for extension), the last extension at $72^{\circ} \mathrm{C}$ for 5 minutes, and closed with a temperature of $24^{\circ} \mathrm{C}$ for 1 minute.

\subsection{Electrophoresis of PCR Product}

Visualization of PCR products made with $2 \%$ agarose gel electrophoresis with a voltage of 80 volts for 1 hour. Each well contains $4 \mathrm{ml}$ gel PCR product and $1 \mathrm{ml}$ of loading dye. Staining of DNA molecules made by soaking the gel in a solution containing Ethidium Bromide (EtBr) for 20 minutes and visualized using UV-transluminator. Documentation DNA band performed using a digital camera.

\subsection{Data Analyses}

Polymorphism data analysis and construction of the phylogenetic tree is done using software NTSYSpc 2:02 (Applied Biostatistic). DNA bands of each RAPD marker transformed in the form of binary numbers 1 and 0 . The number 1 indicates the present of DNA bands and 0 indicating no DNA bands. Dissimilarity matrix was calculated by using distance coefficient. The dissimilarity matrix was employed to construct phylogenetic by the Unweighted Pair-Group Method Arithmetic Average (UPGMA), using the Sequential Agglomerative Hierarchical Nested Cluster Analysis (SAHN-clustering, [12] and TREE program from NTSYS-pc, version 2.02 packages [13]. Bootstrap analysis with permutation 10,000 times were performed by using software Tools for Genetic Analysis (TFPGA 1.3).

\section{RESULTS AND DISCUSSIONS}

\subsection{RAPD Polymorphism}

Polymorphism of RAPD amplification fragments by using five RAPD primers and performed in the PCR tools were resulted 26 fragments, 19 numbers of polymorphic fragment, 7 numbers of monomorphic fragment, and 8 numbers of genotype. Sample DNA fragments resulted by PCR were shown in Figure 2. High number of RAPD polymorphisms and genotypes were found in this observation. These results were similarly with polymorphism of sago palm in the previous study by using RAPD markers for revealing genetic relationship of natural stand of sago palm in Indonesia [14, 15] by using RAPD markers for revealing relationship between geographical distribution and genetic distance of sago palm in Malay Archipelago. Figure 2 showed that the performance samples of DNA bands were amplified by using 5 primer sets. Numbers of fragment DNA band were amplified from each primer, and it was ranging from 3 to 9 fragments. Primers OPAW05, OPA01, and OPA04 were observed overall amplification DNA fragments it shown polymorphic whereas, primer P01 was resulted 3 DNA fragments polymorphic and 5 DNA fragments monomorphic and primer OPD08 was resulted 7 DNA fragment polymorphic and 2 DNA fragments monomorphic. Amplification of DNA sago palm by using those primers set was consistently resulting high polymorphism [16-18]. The polymorphisms of DNA fragments product by using RAPD markers were related to the variation of morphological phenotypic. Morphological characteristics of sago palm in the natural vegetation were observed in the previous study that were reported a large variation [19].

\subsection{Genetic Variations}

The Genetic distances of among individual samples were shown in the Table 1. Individual samples number S03, S04, and S07 were genetically the same because calculation the genetic distances in the Table 


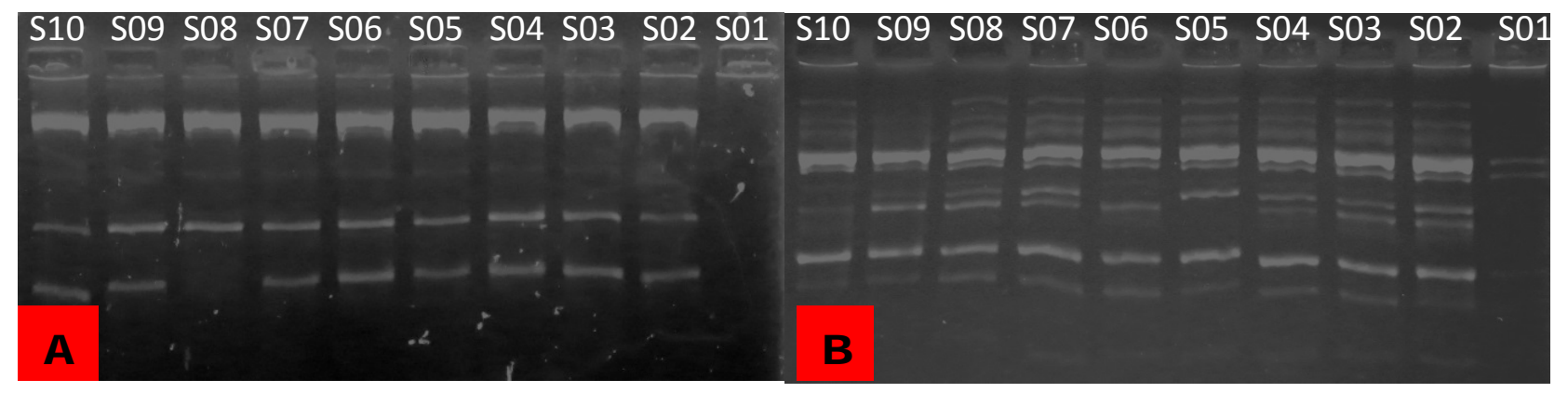

Figure 2. Performance of RAPD fragments by using 5 RAPD primers on $2 \%$ agarose gels. Primer OPA04 (A) and primer OPD08 (B). Individual sample indicated by S01 to S10.

Table 1. Calculation value of distances among sample based on Nei's unbiased (1978) distance.

\begin{tabular}{lcccccccccc}
\hline Sampel & S01 & S02 & S03 & S04 & S05 & S06 & S07 & S08 & S09 & S10 \\
\hline S01 & ***** & & & & & & & & & \\
S02 & 0.7732 & $* * * * *$ & & & & & & & & \\
S03 & 0.6931 & 0.0392 & $* * * * *$ & & & & & & & \\
S04 & 0.6931 & 0.0392 & 0.0000 & $* * * * *$ & & & & & & \\
S05 & 0.6931 & 0.1226 & 0.0800 & 0.0800 & $* * * * *$ & & & & & \\
S06 & 0.7732 & 0.0800 & 0.1226 & 0.1226 & 0.1226 & $* * * * *$ & & & & \\
S07 & 0.6931 & 0.0392 & 0.0000 & 0.0000 & 0.0800 & 0.1226 & $* * * * *$ & & & \\
S08 & 0.6931 & 0.0392 & 0.0800 & 0.0800 & 0.1671 & 0.1226 & 0.0800 & $* * * * *$ & & \\
S09 & 0.6190 & 0.1671 & 0.2136 & 0.2136 & 0.2136 & 0.1671 & 0.2136 & 0.2136 & $* * * * *$ & \\
S10 & 0.8602 & 0.2136 & 0.1671 & 0.1671 & 0.2624 & 0.2136 & 0.1671 & 0.2624 & 0.4249 & $* * * * *$ \\
\hline
\end{tabular}

Notes: S01 to S10 indicated individual samples.

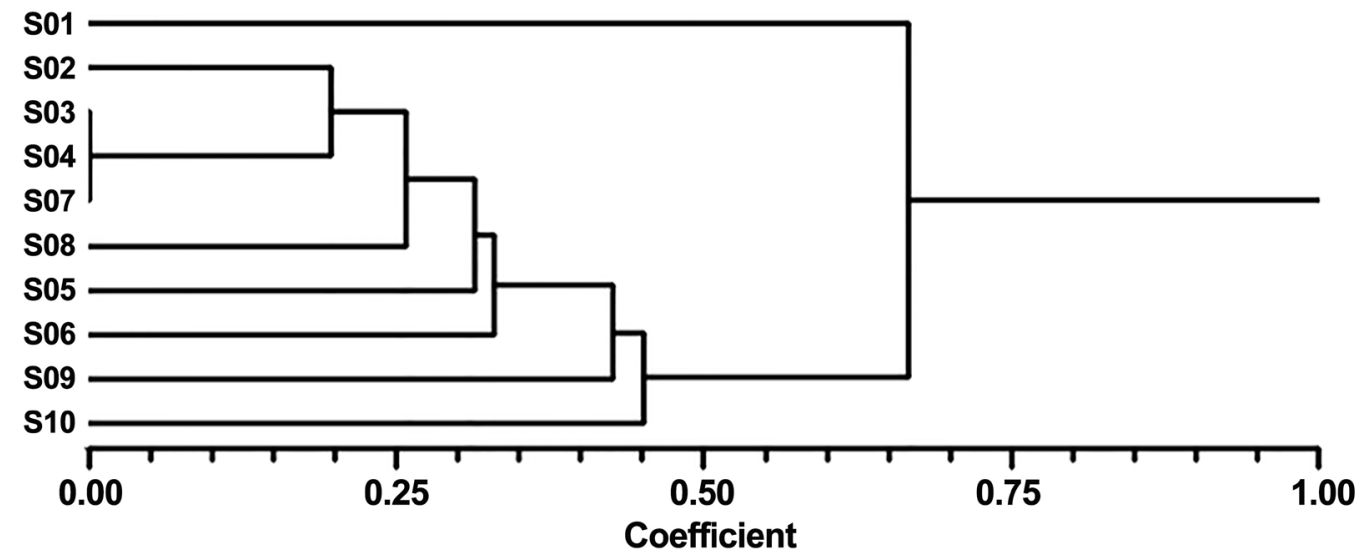

Figure 3. Dendrogram construction of samples based on 5 RAPD markers by using UP-GMA clusters. S01 to S10 indicated individual samples. 
1 were shown zero and the biggest distances between individuals were sample S01 and S10 with the values 0.8602. Sample S01 and S10 were genetically large differences. The previous study were reported that the sago palm in the natural habitat show a lot of variation based on morphological characteristic [19], growth and yield production [20] Chloroplast DNA [17], and specific expression gene [18].

Analysis of phylogenetic trees based on the pattern of polymorphism of RAPD markers was done by using UPGMA method. The dendrogram construction of 10 sago palm samples is presented in Figure 3. Genetic relationships of sago palm progenies that have been grown were divided into four groups in the level dissimilarities $40 \%$ at the position of coefficients 0.40 . Group 1,3 , and 4 just one in individual and Group 2 associated with seven individuals. The molecular observations were indicated that the progenies of sago palm derived from natural pollination were high diversities. The genetic distances among individual progenies were presented in the Table 1 . These features indicated that sago palm in the natural condition was occurred cross-pollination process. In the previous studies were reported that the pollination type of sago palm is crosspollinated, therefore the characters of sago palm progenies were caused diverse [8]. These characters will be expressed after the seeds germination process. Generally, pollination of sago palm occurred a cross pollination because male and female flower mature in different of time period [21].

The progenies of sago palms that derived from naturally pollinated were genetically varied based on RAPD markers. Variations occurred in the progenies of sago palm indicated that the sago palm were estimated naturally cross-pollinated, the nresulting fruits and seeds with genetically differences.

\section{ACKNOWLEDGEMENTS}

Grateful go to the management of MP3EI project with SPPK No.162/SP211/LT/ DRPM/III/2016 from DRPM Directorate General of Strengthen Research and Development (DGSRD) Indonesia for providing financial support in the Fiscal Year 2016. Thanks also to all who were contributed and reviewed in this work.

\section{REFERENCES}

1. Ehara, H. (2012) Potency of Sago Palm as a Carbohydrate Resource for Strengthening the Food Security Program. Japanese Studies Journal, Special Issue, 11-21.

2. Anugoolprasert, O., Ehara, H. and Nato, H. (2014) Growth Response and Nutrient Concentrations of Sago Palm under Aluminium Stress. Thammasat International Journal of Science and Technology, 19, 37-63.

3. Karim, A.A., Pei-Lang Tie, A., Manan, D.M.A. and Zaidul, I.S.M. (2008) Starch from the Sago (Metroxylonsagu) Palm Tree-Properties, Prospects and Challenges as a Source for Food and Other Uses. Comprehensive Reviews in Food Science and Food Safety, 7, 215-228. https://doi.org/10.1111/j.1541-4337.2008.00042.x

4. Bujang, K.B. (2008) Potential of Bioenergy from the Sago Industries in Malaysia. Biotechnology, 14, 8 p.

5. Kanro, M.Z., Rouw, A., Widjono, A., Syamsuddin, Amisnaipa and Atekan (2003) Utilization of Sago Palm in West Papua Province. Jurnal Litbang Pertanian, 22, 116-124. (In Indonesia language)

6. Mofu, S.S. and Abbas. B. (2015) Development of Sago Palm Research and Agroindustry in University of Papua. The $12^{\text {th }}$ International Sago Symposium, Tokyo, 15-17 September 2015.

7. Sofiari, E. and Kirana, R. (2009) Analysis of Segregation Pattern and Distribution of Several Pepper Characteristic Analisis Pola Segregasidan. J. Hort., 19, 255-253. (In Indonesia language)

8. Flach, M. (1997) Sago Palm Metroxylonsagu Rottb. Promoting the Conservation and Used of Unther Utilized and Neglected Crops. 13. Institute of Plant Genetics and Crop Plant Research, Gatersleben/Internasional Plant Genetic Resources Institute (IPGRI), Rome.

9. Powel, W., Castillo, C.O., Chaluers, K.J., Provan, J. and Waugh, R. (1995) Polymerase Chain Reaction BasedAssays for the Characterization of Plant Genetic Resources. Electrophoresis, 16, 1726-1730.

https://doi.org/10.1002/elps.11501601285 
10. Colombo, C., Second, G., Valle, T.L. and Charrier, A. (1998) Genetic Diversity Characterization of Cassava Cultivars (Manihotesculenta Cranz.) RAPD Markers. Genetics and Molecular Biology, 21, 69-84. https://doi.org/10.1590/S1415-47571998000100018

11. Ferdinandez, Y.S.N., Somers, D.J. and Coulman, B.E. (2001) Estimating the Genetic Relationship of Hybrid Bromegrass to Smooth Bromegrass and Medow Bromegrass Using RAPD Markers. Plant Breeding, 120, 149-153. https://doi.org/10.1046/j.1439-0523.2001.00555.x

12. Sneath, P.H. and Sokal, R.R. (1973) Numerical Taxonomy. Freeman, San Francisco, 573 p.

13. Rohlf, F.J. (1998) NTSYS-pc. Numerical Taxonomy and Multivariate Analysis System, Version 2.02. Exeter Software, New York.

14. Abbas, B., Bintoro, M.H., Sudarsono, Surahman, M. and Ehara, H. (2009) Genetic Relationship of Sago Palm (Metroxylon sagu Rottb.) in Indonesia Based on RAPD Markers. Journal of Biological Diversity, 10, 168-174. https://doi.org/10.13057/biodiv/d100402

15. Ehara, H., Kosaka, S., Shimura, N., Matoyama, D., Morita, O., Naito, H., Mizota, C., Susanto, S., Bintoro, M.H. and Yamamotom, Y. (2003) Relationship between Geographical Distribution and Genetic Distance of Sago Palm in Malay Archipelago. Sago Palm, 11, 8-13.

16. Abbas, B., Bintoro, M.H., Surahman, M. and Ehara, H. (2009) Genetic Relationship of Sago Palm (Metroxylon sagu Rottb.) in Indonesia Based on RAPD Markers. Journal of Biological Diversity, 10, 168-174. https://doi.org/10.13057/biodiv/d100402

17. Abbas, B., Renwarin, Y., Bintoro, M.H., Surahman, M. and Ehara, H. (2010) Genetic Diversity of Sago Palm in Indonesia Based on Chloroplast DNA (cpDNA) Markers. Journal of Biological Diversity, 11, 112-117. https://doi.org/10.13057/biodiv/d110302

18. Abbas, B. and Ehara, H. (2012) Assessment Genetic Variation and Relationship of Sago Palm (Metroxylon sagu Rottb.) in Indonesia Based on Specific Expression Gene (Wx Genes) Markers. African Journal of Plant Science, 6, 314-320. https://doi.org/10.5897/AJPS12.015

19. Dewi, R.K., Bintoro, M.H. and Sudrajat. (2016) Morphological Characteristic and Yield Potential of Sago Palms (Metroxylon spp.) Accession in South Sorong Regency, West Papua. Jurnal Agronomi Indonesia, 44, 91-97.

20. Jong, F.S. (2011) Growth and Yield Parameters of Natural Sago Forest for Commersial Operations. The $10^{\text {th }} \mathrm{In-}$ ternational Sago Symposium, Bogor-Indonesia, 29-31 October 2011.

21. Jong, F.S. (1995) Research for the Development of Sago Palm (Metroxylon saguRottb.) Cultivation in Sarawak, Malaysia. Department of Agriculture, Kuching, Sarawak, Malaysia. 
Submit or recommend next manuscript to SCIRP and we will provide best service for you:

Accepting pre-submission inquiries through Email, Facebook, LinkedIn, Twitter, etc. A wide selection of journals (inclusive of 9 subjects, more than 200 journals)

Providing 24-hour high-quality service

User-friendly online submission system

Fair and swift peer-review system

Efficient typesetting and proofreading procedure

Display of the result of downloads and visits, as well as the number of cited articles Maximum dissemination of your research work

Submit your manuscript at: http://papersubmission.scirp.org/

Or contact ns@scirp.org 